\title{
Potential of endophytic bacteria from rice root as potassium solvent
}

\author{
WARZATULLISNA ${ }^{1}$, LENNI FITRI $^{2, \bullet}$, YULIA SARI ISMAIL ${ }^{2}$ \\ ${ }^{1}$ Program of Biologi, Postgraduate Program, Faculty of Matematics and Natural Sciences, Universitas Syiah Kuala. Jl. Syech Abdurrauf No. 3, Kopelma \\ Darussalam, Syiah Kuala, Banda Aceh 23111, Aceh, Indonesia \\ ${ }^{2}$ Departement of Biology, Faculty of Mathematics and Natural Sciences, Universitas Syiah Kuala. Jl. Syech Abdurrauf No. 3, Kopelma \\ Darussalam, Syiah Kuala, Banda Aceh 23111, Aceh, Indonesia. "email: lennifitri@unsyiah.ac.id
}

Manuscript received: 9 March 2019. Revision accepted: 22 April 2019.

\begin{abstract}
Warzatullisna, Fitri L, Ismail YS. 2019. Potential of endophytic bacteria from rice root as potassium solvent. Biodiversitas 20: 1303-1308. Endophytic bacteria live in plant tissues and known to have many benefits for plant growth. One function of endophytic bacteria are known to be able to dissolve potassium. Potassium is one of the macronutrients that plays an important role in plant growth and development. This study aims to obtain endophytic bacterial isolates from the roots of rice plants (Oryza sativa L.) which have potential as potassium solvents, identify the endophytic bacteria in morphologically and physiologically, and analysis of the selected isolate 16S rRNA genes. Selected endophytic bacterial isolates from the test of dissolving potassium on medium Alexandrov, measured clear zone using calipers and continued with biochemical tests using KIT DL-96E also identified based on 16S rRNA gene and compared for their close relationship with reference strains available in the Bank Genes. Based on the isolation results, 7 isolates from the roots of rice were obtained. Six isolates of endophytic bacteria were able to dissolve potassium. EPK3 isolates were the isolates that are capable of dissolving the highest potassium in Alexandrov media with a $17.9 \mathrm{~mm}$ potassium dissolution index. EPK3 isolates also produce inhibit the growth of Xanthomonas oryzae with a $1.2 \mathrm{~mm}$ inhibition zone. Physiological identification showed that EPK3 isolates were Enterobacter cloaceae bacteria with $93.79 \%$ of similarity. Based on the 16SrRNA gene showed that EPK3 isolates were closely related to E. cloaceae strain SBP-8 with similarity rate is $99 \%$.
\end{abstract}

Keywords: Endophyte, rice root, potassium solvent bacteria, Enterobacter

\section{INTRODUCTION}

Aceh is one of rice production centers provinces in Indonesia which is targeted to be able to self-sufficiency in rice and become a national food barn. Rice production centers in Aceh are located in North Aceh, Bireuen and Aceh Besar Districts. Rice is the most important food crop in Indonesia because almost all residents use rice as a staple food. Rice (Oryza sativa L.) is one type of food crop from the genus Oryza, which belongs to the Poacea tribe. Rice plants have very short stems, lanceolate leaves, flowers are compounded and has fiber roots (Fitri 2015).

Root growth in rice starts from the seed germination process. The first root that appears is taproot, then after 5-6 days, the fiber roots will grow. The roots of rice plants have root hair which plays an important role in nutrient absorption, water and as a site of interaction between plants and soil microbes. For normal growth, each plant needs nutrients such as potassium elements that can be obtained from the soil (Sudarma 2013).

Nutrien is one of the macronutrients that play an important role in plant growth and production. The main function of potassium is to stimulate the translocation of carbohydrates from leaves to plant organs, especially carbohydrate-depositor organs, activates the work of several enzymes, an important regulator in cells osmotic mechanism, directly influencing the semi permeability of membranes and phosphorylation in chloroplasts (Yuliprianto and Hieronymus 2010 ).
The amount of total potassium in soil is quite large, but its availability for plant growth is very little. Most potassium can be dissolved by bacteria. The role of potassium solvent bacteria is known to be able to providing available potassium elements to plants. Potassium solvent bacteria are often used as one of the inoculants in biological fertilizers to help increase soil fertility which can increase the yield of food crops such as rice (Don and Diep 2014).

One of the bacteria known to have the ability as a potassium solvent is endophytic bacteria. Endophytic bacteria are symbiotic microorganisms that live in plant tissues and do not cause disease to their host plants. Endophytic bacteria can benefit plants by producing growth regulator substances, antibiotic production, nitrogen fixation, and increasing host plant resistance to pathogens and parasites (Bhore and Sathisha 2010).

Information related to bacteria capable of dissolving potassium is quite small, although it is known that certain groups of bacteria are able to dissolve potassium minerals into a soluble form that it can be utilized by plants. This is an interesting challenge to study regarding the ability of potassium solvent bacteria isolated from the rice roots that it is expected to be a beneficial development in agriculture in the future. 


\section{MATERIALS AND METHODS}

\section{Time and Place}

This research was conducted from June 2018 to January 2019. At Laboratory of Microbiology of the Faculty of Mathematics and Natural Sciences, Syiah Kuala University, Aceh, Indonesia, Laboratory of Biomolecular Brackish Water Aquaculture (BPBAP) Ujung Batee, Aceh and UPTD Aceh Health Laboratory Center. The taken of rice root samples used in this study was collected from the rice fields of Tungkop Village, Aceh Besar District.

\section{Materials}

The tools used in this study are oven, laminar air flow cabinet (LAFC), Polymerase Chain Reaction (PCR), spatula, aluminium foil, ose, wrap, autoclaves, Erlenmeyer, hotplates, bunsen burners, digital scales, mortars and pestels, label paper, test tubes, Petri dishes, pipettes, micropipettes, tip pipettes, object glass tweezers, cover glass, microtube, microscope, centrifugation machine, laminar air flow cabinet, and cameras digital.

The ingredients used in this study are (Oryza sativa. L), Xanthomonas oryzae, Tryptic Soy Broth (TSB), nutrient agar (NA), nutrient broth (NB), alcohol 70\%, natrium hypochlorite, $\mathrm{NaCl}$ 0,9\%, Nicotiana tobacum, medium Alexandrov, Wizard DNA Genome Purification KitPromega, primer Bact 27F-Uni dan 1492R, ddH $\mathrm{d}_{2} \mathrm{O}$ sterile, nucleic lysis solution, RNAse solution, protein precipitation solution, isopropanol absolute, ethanol $70 \%$, DNA rehydration solution, Go Taq Green, dan NFW

\section{Procedures}

Isolation of endophytic bacteria from rice roots

Endophytic bacteria isolated from the roots of the Ciherang rice plant, which is around 60 days old, were obtained at the Tungkop rice fields in Aceh Besar. The stages of isolation of endophytic bacteria from plant roots begin with the surface sterilization process. The sample is washed with running water until it is clean, then dried and weighed as much as 1 gram. The samples were soaked for 6 minutes in $70 \%$ alcohol and 4 minutes in 5\% sodium hypochlorite. Samples were rinsed again with running water three times, taken 1 gram of the sample and ground, grown and purified it in NA media (Strobel and Daisy 2003).

\section{Hypersensitive response test}

Endophytic bacterial isolates that have been grown on NB media was taken using $100 \mu \mathrm{l}$ of micropipette, then injected on the side of Nicotiana tabacum leaf and incubated in room temperature for 48 hours. Observations were made by looking at necrosis reactions in $N$. tabacum leaf. Negative reacting bacteria that did not show damage symptoms in $N$. tabacum leaves were used for further tests (Schaad et al. 2001).

\section{Antagonistic test of endophytic bacteria against pathogenic bacteria \\ Endophytic bacterial isolates were tested by pathogenic Xanthomonas oryzae bacteria. The test bacterial suspension}

was adjusted to $0.5 \mathrm{McFarland}$ 's turbidity standard. A total of $25 \mu \mathrm{L}$ of Xanthomonas oryzae were grown on NA media using the scatter method. Endophytic bacterial isolates were taken using a cork borer (diameter $=7 \mathrm{~mm}$ ), transferred to NA media containing test bacteria and incubated for 24 hours at room temperature. Observations were made by measuring the inhibitory zone formed using a caliper. The inhibitory zone is an indication of bacterial sensitivity to the test material expressed by the clear zone diameter (Vandepitte et al. 2003).

\section{Potassium dissolving ability test}

Twenty-four hours-old endophytic bacterial isolates were inoculated on the surface of solid medium Alexandrov (Hu et al. 2006) and incubated for 4 days in room temperature. The growth of potassium-solvent bacterial colonies was characterized by the formation of clear zones around isolates of endophytic bacteria, which means that the isolates were able to dissolve potassium. The clear zone formed around the colony was measured and calculated by the potassium dissolution index (IP) in each colony with the following equation.

$\mathrm{IP}=\frac{\text { clear zone diameter }(\mathrm{mm})-\text { colony diameter }(\mathrm{mm})}{\text { colony diameter }(\mathrm{mm})}$

\section{Morphological characterization and biochemical tests}

Morphological observation of colonies was carried out after obtaining the pure culture. Macroscopic observations include the shapes, colors, edges, and elevation of bacterial colonies. Stained bacterial isolates were observed using a microscope at 1000x magnification. The biochemical test used KIT DL-96E by inserted $100 \mu \mathrm{L}$ of bacterial suspension into each well and incubated for 24 hours at $37^{\circ} \mathrm{C}$. Test cart reading used the DL-96 II instrument to analyze test results.

\section{Molecular identification}

The sequencing of the 16S rRNA gene was carried out by sequencing nucleotides, using the services of PT. Genetics Science that works with $1^{\text {st }}$ Base. Sequencing results obtained via e-mail. The results of base sequence by sequencing 16S rRNA genes from combining two types of primers were analyzed by the DNA Baser assembly program. The consensus from the results of merging sequences was stored in the FASTA format. The base sequence of isolates then be compared to Bank Genes used the Basic Alignment Search Tools nucleotide (BLAST-N). BLAST-N can be accessed on the National Center for Biotechnology Information (NCBI) website http://blast.ncbi.nlm.nih.gov/Blast.cgi. Furthermore, phylogenetic tree construction was carried out using the Molecular Evolutionary Genetics Analysis Version 6.0 program (Tamura et al. 2013). 


\section{RESULTS AND DISCUSSION}

\section{Characteristics of rice root endophytic bacteria}

The results of bacterial isolation obtained from rice roots were seven endophytic bacteria. The shapes and colors of the obtained colonies were variants. Generally, single colonies of purified endophytic bacteria have white color, round with slippery edges, and raised elevation. The color of the bacterial colonies varies due to the presence of its pigments. Some external factors that can change its genuine color in media are medium, $\mathrm{pH}$ and temperature. However, the appearance of this pigment does not indicate the original characteristics of these bacteria. González-Rey et al. (2004) stated that the color of bacterial colonies was caused by the presence of pigments such as carotenoids, anthocyanin, melanin, tripirilmeten and phenazine. As follows is the table of the morphological characteristics of endophytic bacteria from the seven isolates of rice root endophytic bacteria (Table 1).

The results of the Gram staining test had founded three Gram-positive bacteria isolates were EPK1, EPK5, and EPK6 while four bacterial isolates EPK2, EPK3, EPK4 and EPK7 were Gram-negative bacteria. Trivedi et al. (2010) stated that the nature of Gram-positive bacteria has a greater number of peptidoglycan on the cell walls compared to Gram-negative bacteria. The cell walls of Gram-positive bacteria consisted of $40-80 \%$ peptidoglycan from the dry weight of the cell walls. This peptidoglycan is about 40 or more in the deeper layer of Gram-positive bacteria. The thickness of the cell walls is around 30-80 nm. In general, Gram-negative bacterial cell walls are thinner than Gram-positive bacteria. Gram-negative bacteria contained a higher percentage of lipids than Grampositive bacteria.

Mano et al. (2007) stated that endophytic bacteria can be found in agricultural crops, such as rice. Rice plants have a long growing period, so there is a possibility of endophytic bacteria got into the rice plant tissue. Endophytic bacteria will settle and produce certain compounds or secondary metabolites that were the same as produced by the host plant. Endophytic bacteria in rice can migrate from the surface of the plant to the inside of the plant or vice versa. Some genus of endophytic bacteria that can be isolated from rice roots such as Bacillus, Mycobacterium, Enterobacter, and Chryseobacterium.

Table 1. Characteristics of morphology of endophytic bacteria

\begin{tabular}{lllll}
\hline $\begin{array}{c}\text { Isolate } \\
\text { code }\end{array}$ & \multicolumn{3}{c}{ Form } & Characteristics of morphology \\
Edge & Elevation & Color \\
\hline EPK1 & Circular & Entire & Convex & White \\
EPK2 & Circular & Entire & Convex & White \\
EPK3 & Circular & Entire & Raised & White \\
EPK4 & Filamentous & Filiform & Raised & White \\
EPK5 & Circular & Entire & Raised & White \\
EPK6 & Circular & Entire & Raised & White \\
EPK7 & Concentric & Lobate & Raised & Cream \\
\hline
\end{tabular}

Note: EPK: Endophytes Potassium Solvents

\section{Hypersensitive response test}

Seven isolates of endophytic bacteria which isolated from rice roots were tested for hypersensitivity of the tobacco plant leaves. All seven hypersensitive test results from the injected rice root endophytic bacteria isolates on the tobacco plant leaves was obtained that six isolates of endophytic bacteria EPK1, EPK2, EPK3, EPK5, EPK6, and EPK7 showed no symptoms of necrosis in tobacco leaves (negative reaction), whereas EPK4 isolates showed symptoms of necrosis characterized by a positive reaction (Figure 1).

Bacterial isolates that did not show symptoms of necrosis in tobacco leaves (negative reaction) were used for further testing. Selection with hypersensitivity testing of isolates of potassium solvent bacteria is intended to obtain isolates that do not have pathogenic properties in plants. So that when the potassium solvent bacterial isolates were applied to cultivated plants, the isolates were not antagonistic to the plants. This is consistent with the statement of Zou et al. (2006) that a hypersensitive reaction test was conducted to determine the pathogenicity of endophytic bacteria based on plant defense reactions seen on the leaves of tobacco plants with symptoms of necrosis. Wulandari (2012), states that a hypersensitive response is defined as a defense reaction that occurs rapidly in plants. Plants will show a defense reaction to confront incompatible pathogens.

\section{Antagonistic test of endophytic bacteria towards pathogenic bacteria}

Based on the results of the hypersensitivity test, six isolates that did not show symptoms of necrosis were taken for antagonistic testing of plant pathogenic bacteria. Among the six isolates tested, there were two isolates (EPK3 and EPK7) which were able to produce inhibitory zones against Xanthomonas oryzae. EPK1, EPK2, EPK5, and EPK6 are not able to inhibit the growth of Xanthomonas oryzae bacteria. The compounds produced by each endophytic bacteria isolate are different, as not all isolates have the ability to inhibit the growth of pathogenic bacteria. Andri (2004), stated that Streptomyces isolates have the ability to inhibit the growth of Xanthomonas saxonopodis bacteria. Endophytic bacteria test on plant pathogenic bacteria was to provide information on which isolates that are not pathogenic and able to dissolve potassium for optimal plant growth.

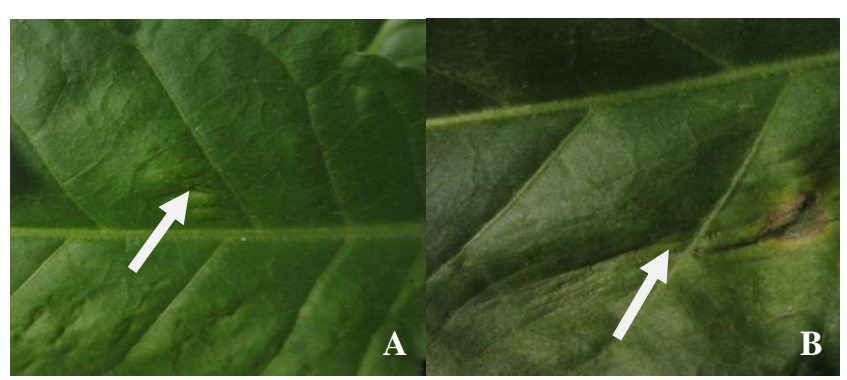

Figure 1. Tobacco leaves injected with endophytic bacteria. Note: A. Control (sterile aquadest), B. EPK4 isolates are pathogenic 


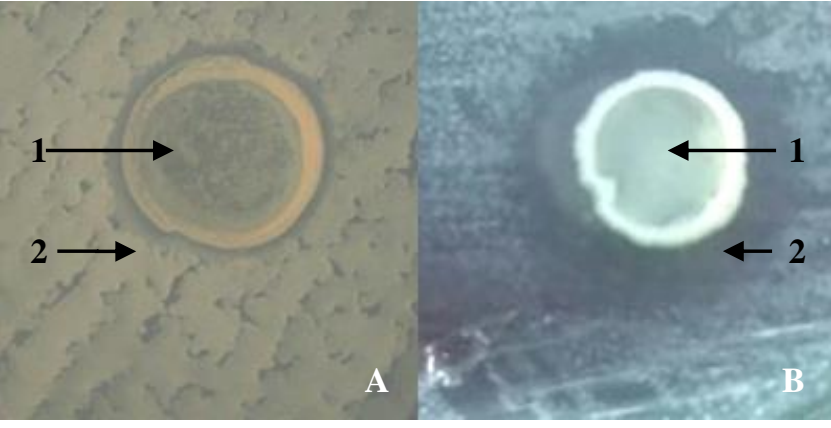

Figure 2. The inhibition zone in the Xanthomonas oryzae test bacteria. Note: A. EPK3, B. EPK7, 1. Endophytic bacteria, 2. Pathogenic bacteria

The inhibitory zone around the bacterial colonies indicates of an antibiotic mechanism. These bacterial isolates can produce secondary metabolites that can diffuse into the media and inhibit the growth of Xanthomonas oryzae. EPK3 isolates with an inhibition zone of $1.2 \mathrm{~mm}$ can be categorized into weak categories, while EPK7 isolates with a $17.5 \mathrm{~mm}$ inhibition zone can be categorized as a strong inhibitory zone. This is in accordance with Morales et al. (2003), stated that the inhibitory zone activity was categorized into four, that is a weak activity $(<5 \mathrm{~mm})$, moderate $(5-10 \mathrm{~mm})$, strong $(>10-20 \mathrm{~mm})$, and very strong (>20-30 $\mathrm{mm})$.

Figure 2 shows the ability of endophytic bacteria to inhibit Xanthomonas oryzae, 2 of 6 endophytic bacteria (EPK3 and EPK7). It could inhibit Xanthomonas oryzae the pathogen of rice plants and dissolve potassium too. Each bacterial species has a genetic ability that is different in producing organic acids both in number and type during growth. Different genetic abilities of EPK3 and EPK7 bacteria can inhibit bacterial growth and dissolve potassium. Mineral dissolution is generally caused by the production of organic acids such as acetic acid, formic acid, lactic acid, oxalic acid, malic acid and citric acid produced by microbes. This amount and type of organic acids play a role in determining the high dissolution of organic minerals in the soil (Richardson 2001).

\section{Potassium dissolve ability test}

Based on the test of the ability to dissolve potassium, it was found that the six endophytic bacterial isolates were able to dissolve feldspar (KAlSi3O8) which is the source of potassium in Alexandrov media. This is in accordance with Ghevariya (2014), who stated that the microbes that grew in Alexandrov media and had the ability to form clear zones were assumed to have capability to dissolve potassium. The biggest isolate in producing clear zones was EPK3, while the one that produced the smallest clear zone was EPK2 isolate. Based on the wide clear zone around the bacterial colonies on the Alexandrov media, all six endophytic bacteria isolates was calculated for its potassium dissolution index. The isolate which has the highest index was EPK3. The potassium dissolution index in EPK3 isolates was $17.9 \mathrm{~mm}$ which would be used for molecular identification. Mutmainnah et al. (2015) showed that six out of fifteen selected microbes inoculated on Aleksandrov media with feldspar potassium as sources, A4b isolate was the most efficient microbes to dissolved feldspar and its highest potassium dissolution index was $9.53 \mathrm{~mm}$.

The dissolution of potassium in the six endophytic bacteria seen in (Figure 3) shows a varied index, and in sequence, the highest potassium dissolution index were EPK3 (17.9), EPK7 (16.9), EPK1 (15.9), EPK5 (15.9), EPK6 (14.4) and EPK2 (14.2). Each isolate had a different potassium dissolution index because the dissolution of minerals can be affected by various things. Ismail and Hanudin (2005) stated that mineral dissolution was influenced by the type of minerals, $\mathrm{pH}$ of the media, type and amount of organic acid released by microbes.

Basak and Biswas (2010) stated that each potassium solvent microbe produced different types and quantities of organic acids. It is possible that one type of potassium solvent microbes produce more than one kind of organic acid. These organic acids speed up the weathering process of potassium-carrying minerals, led the potassium to be detached and became a dissolved form. Organic secretions released from bacteria reacted with potassium-carrying minerals on feldspar and accelerated the weathering of feldspar that was added into the media.

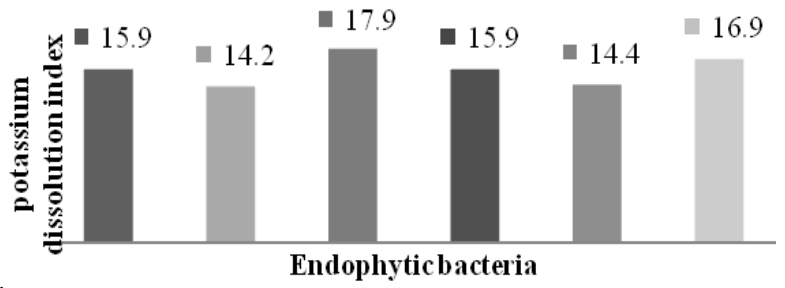

Figure 3. Index of potassium solvent bacteria

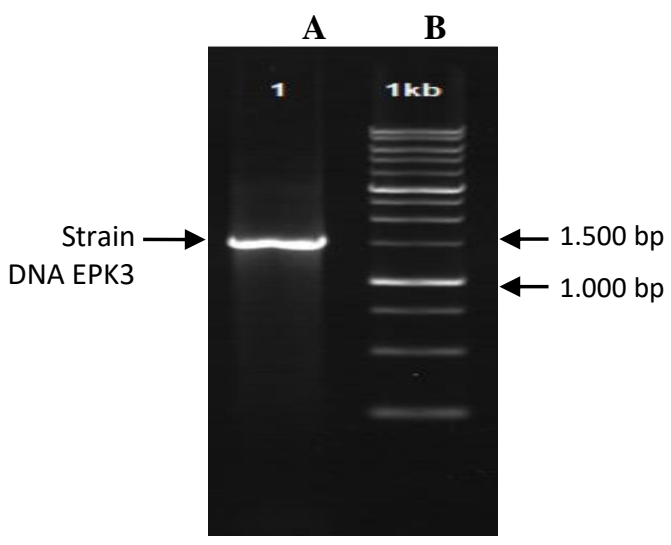

Figure 4. Results of 16S rRNA gene amplification from EPK3 isolates. Note: A. Lane 1 sample, B. Lane 2 DNA markers 


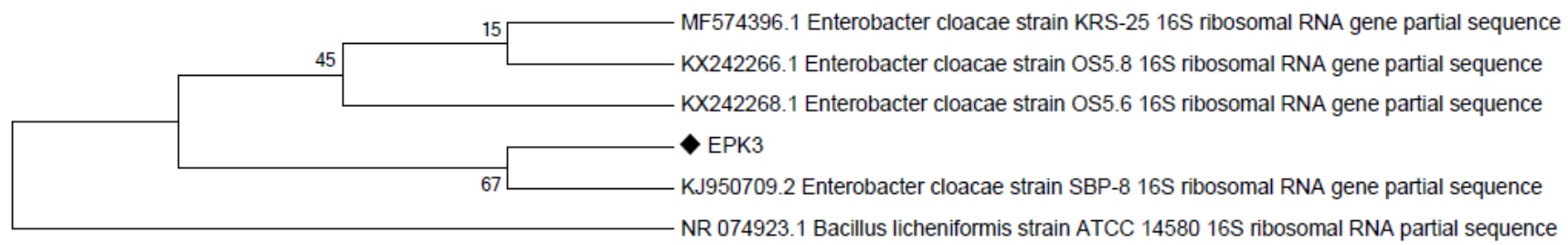

Figure 5. Construction of EPK3 phylogenetic trees based on the 16S rRNA gen

Herman (2008) stated that feldspar was a natural silicate which generally has a ring structure formed from a tetrahedral structure. Potassium feldspar consisted of three silicon tetrahedral and aluminum tetrahedral. Ryan et al. (2008) stated that Pseudomonas sp., Enterobacter sp., Staphylococcus sp., Azotobacter sp., and Azospirilum sp. were endophytic bacteria that play a role in plant growth, while endophytic bacteria that had a role in health and plant protection includes: Pseudomonas sp., Serratia sp., Clavibacter sp., and Bacillus sp.

\section{Identification of selected endophytic bacteria isolate}

One of the highest potassium solvent potential isolates, EPK3, was identified molecularly using $16 \mathrm{~S}$ rRNA sequence analysis. The extracted DNA would be used as a template for the amplification process. Later, 16S rRNA sequence analysis was carried out using the BLAST program.

Based on the DNA band on Figure 4, it can be seen that the resulting DNA fragments were about $1500 \mathrm{bp}$ in size. This amplification indicated the 16s rRNA area as a target because the length of the fragments produced was as expected. The process of sequencing the 16S rRNA gene was obtained from the results of amplification which carried out by the provider of sequencing services, PT. Science Genetics, Jakarta. BLAST analysis was conducted to see the similarities between the sequences of this research to sequences that were previously stored in the GenBank DNA Database.

Based on these results, it can be seen that the sequence of EPK3 isolates had $99 \%$ similarity with the Enterobacter cloaceae sequences that stored in the NCBI GenBank DNA database. This was in accordance with Claverie (2004) who stated than DNA sequence was most similar if query cover value close to $100 \%$ and e-value was close to 0.0 . Based on BLAST results on EPK3 endophytic bacteria, it was necessary to construct a phylogeny tree to describe the position and kinship between sequences of EPK3 isolates and sequences that stored in the GenBank DNA Database.

The analysis results of $16 \mathrm{~S}$ rRNA gene was an endophytic bacterial isolate that capable of dissolved potassium had the closest resemblance to E. cloaceae strain SBP-8. The bootstrap value in phylogenetic tree construction was $67 \%$. Based on the results of physiology tests, EPK3 isolate could fermentate few types of carbohydrates such as glucose, lactose, sucrose, and maltose. EPK3 also showed positive results on catalase, org, arg, citrate, vp, melf, rhaf, esculin, onpg, sorf, malf, and celf tests. Identification of EPK3 using KIT DL 96E resulted in this isolate as E. cloaceae bacteria with $93.79 \%$ similarity. Hoffmann et al. (2015) stated that E. cloaceae is a Gram-negative bacterium that had capability to ferment sucrose and shown positive result to $\mathrm{vp}$, esculin, Dmelibiose, 3-, and D-sorbitol tests.

Identification of EPK3 endophytic bacteria in biochemically and molecularly bring out the same results with physiology tests. Singh (2017) stated that E. cloaceae is a genus of Gram-negative, facultative anaerobes, rodshaped, motile and does not form spores. E. cloaceae bacteria are found vastly in nature, and one of the types of plant growth promoting bacteria (PGPB). E. cloaceae was known to have the ability to use a variety of various carbohydrates so that it can adapt to various kinds of plant roots.

In conclusion, six isolates of endophytic bacteria isolated from rice roots were able to dissolve potassium (EPK1, EPK2, EPK3, EPK4, EPK5, and EPK6). EPK3 isolate was capable to dissolve potassium in Alexandrov media with highest clear zone was $17.9 \mathrm{~mm}$. Two of six isolates (EPK3 and EPK7) endophytic bacteria also produce inhibitory zones against Xanthomonas oryzae. EPK3 isolates with an inhibition zone of $1.2 \mathrm{~mm}$ and EPK7 isolates with a $17.5 \mathrm{~mm}$. Based on the physiology tests, EPK3 isolates were identified as Enterobacter cloacea bacteria with a similarity rate of $93.79 \%$. Based on molecular identification of the 16S rRNA gene, it showed that EPK3 isolate was closely related to E. cloaceae strain SBP-8 with a similarity rate was $99 \%$.

\section{ACKNOWLEDGEMENTS}

Thank you to the General Director of Higher Education (DGHE), Ministry of Research, Technology and Higher Education of the Republic Indonesia that has funded the master's thesis research in 2019. The author would like to thank the DGHE for its PTM Scholarship of the magister programme for 2019 . 


\section{REFERENCES}

Basak BB, Biswas DR. 2010. Co-inoculation of potassium solubilizing and nitrogen-fixing bacteria on solubilization of waste mica and their effect on growth promotion and nutrient acquisition by a forage crop. J Biol Fertil Soil. 46: 641-648.

Bhore SJ, Sathisha G. 2010. Screening of endophytic colonizing bacteria for cytokinin-like compounds: crude cell-free broth of endophytic colonizing bacteria is unsuitable in cucumber cotyledon bioassay. $\mathrm{J}$ Agricult Sci 6 (4): 345-352.

Don NT, Diep CN. 2014. Isolation, characterization, and identification of phosphate and potassium solubilizing bacteria from weathered materials of granite rock mountain. J Life Sci. 2 (5): 282-291.

Firtri N, Syechalad MN. Syahnur S. 2015. Analisis faktor-faktor yang mempengaruhi produksi padi di Propinsi Aceh. J Ilmu Ekonomi 3 (1) 81-95. [Indonesian]

Ghevariya KK, Desai PB. 2014. Rhizobacteria of sugarcane in vitro screening for their plant growth promoting potential. J Sci 3 (4): 52 58.

González-Rey C, Svenson SB, Bravo L, Siitonen A, Pasquale V, Dumontet S, Ciznar I, Krovacek K. 2004. Serotypes and antimicrobial susceptibility of Plesiomonas shigelloides isolate from humans, animals and aquatic environments in different countries. Comp Immunol Microbiol Infect Dis 27: 129-139.

Herman DZ. 2008. Pendayagunaan mineral untuk menjadi permata. Jurnal Geologi 5 (7): 4-5. [Indonesian]

Hoffmann H, Stindl S, Ludwig W, Stumpf A, Mehlen A, Heesemann J, Monget D, Schleifer KH, Roggenkamp A. 2005. Reassignment of Enterobacter dissolvens to Enterobacter cloacae as E. cloacae subspecies dissolvens comb. nov, and amended description of Enterobacter asburiae and Enterobacter kobei. J Syst Appl Microbiol 28: 196-205.

Hu XJ, Chen, Guo J. 2006. Two phosphate and potassium solubilizing bacteria isolated from Tianmu Mountain, Zhejiang, China. J Microbiol Biotechnol 22: 983-990.

Mano H, Tanaka F, Nakamura C. 2007. Culturable endophytic bacteria flora of the maturing leaves and roots of rice plants (Oryza sativa) cultivated in a paddy field. J Microb Environ 22: 175-185.

Morales G, Sierra P, Mancilla, Paredes A, Loyola LA, Gallardo O and Borquez J. 2003. Secondary metabolites from four medicinal plants from Northern Chile, antimicrobial activity, and biotoxicity against Artemia salina. J Chile Chem 48 (2): 23-24.

Mutmainnah L, Tri CS, Arie M. 2015. Inventory and test of potassium solubilization ability using potassium solubilizing microbes from rhizosphere of sugarcane plant (Saccharum sp.). J Berkala Ilmiah Pertanian 1 (1): 20

Richardson AE. 2001. Prospect for using soil microorganisms to improve the acquisition of phosphorus by plants. Aust J Plant Physiol 58: 797906.

Ryan RP, Germaine K, Franks A. 2008. Bacterial endophytes: recent development and application. J Microbiol Lett 278: 1-9.

Schaad W, Jones JB, Chun W. 2001. Laboratory Guide for Identification of Plant Pathogenic Bacteria. 3rd ed. APS Press, St. Paul, USA.

Sigh RP. 2017. Bio-inoculation of plant growth promoting rhizobacterium Enterobacter cloceae ZNP-3 increased resistance against salt and temperature stresses in wheat plant (Triticum aestivum L.). J Plant Growth Regul 36: 783-798.

Strobel G, Daisy B. 2003. Bioprospecting for microbial endophytes and their natural products. J Microbiol Mol Biol 67 (4): 491-502.

Sudarma IM. 2013. Penyakit Tanaman Padi (Oryza sativa L.). Edisi Pertama. Graha Ilmu, Yogyakarta. [Indonesian]

Tamura K, Stecher G, Peterson D, Filipski A, Kumar S. 2013. MEGA6: molecular evolutionary genetics analysis version 6.0. J Mol Biol Evol 30 (12): 2725-2729.

Trivedi PC, Pandey S, Bhadauria S. 2010. Text Book of Microbiology. Aavishkar Publishers, India.

Vandepitte J, Engbaek K, Rohner P, Piot P, Heuck CC, et al. 2003. Basic Laboratory Procedures in Clinical Bacteriology. 2nd ed. World Health Organization, Geneva.

Wulandari H, Zakiyatulyaqin and Supriyanto. 2012. Isolasi dan pengujian bakteri endofit dari tanaman lada (Piper ningrum L.) sebagai antagonis terhadap patogen hawar beludru (Septobasidium sp.). J Perkebunan dan Tropika 12 (12): 23-24. [Indonesian]

Yuliprianto, Hieronymus. 2010. Biologi Tanah dan Strategi Pengelolaannya. Graha Ilmu, Yogyakarta. [Indonesian]

Zou LF, Wang X, Xiang. 2006. Elucidation of the hrp clusters of Xanthomonas oryzae $\mathrm{pv}$. oryzicola that control the hypersensitive response in non-host tobacco and pathogenicity in susceptible host rice. J Appl Environ Microbiol 72 (9): 6212-6224. 